\begin{tabular}{|c|c|c|}
\hline 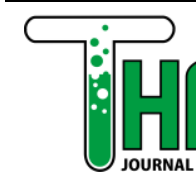 & TURAL SCIENCE TEACHING & $\begin{array}{l}\text { Thabiea : Journal of Natural Science Teaching } \\
\text { Vol. } 4 \text { (2), pp. } 207-216,2021 \\
\text { Available online at } \\
\text { http://journal.iainkudus.ac.id/index.php/Thabiea } \\
\text { p-issn: } 2580-8474 \text {, e-issn: } 2655-898 X\end{array}$ \\
\hline
\end{tabular}

\title{
Digital Literacy of Pre-Service Science Teachers as Reflection of Readiness Toward Online Learning in New Normal Era
}

\author{
Aldeva Ilhami ${ }^{1 *}$, Diniya Diniya ${ }^{2}$, Susilawati $^{3}$, Rian Vebrianto $^{4}$ \\ Universitas Islam Negeri Sultan Syarif Kasim Riau ${ }^{1,2,3,4}$ \\ *Correspondence: aldeva.ilhami@uin-suska.ac.id
}

\begin{tabular}{|c|c|}
\hline & Abstract \\
\hline $\begin{array}{l}\text { Keywords: } \\
\text { Digital Literacy, } \\
\text { Science Education, } \\
\text { Pre-service Teacher, } \\
\text { Online Learning }\end{array}$ & $\begin{array}{l}\text { The Covid-19 outbreak affects education sector thus the teaching is undertaken } \\
\text { remotely. Teachers and students use digital platforms to continue the teaching-learning } \\
\text { processes. The present study was carried out to determine the digital literacy of pre- } \\
\text { service science teachers at UIN Sultan Syarif Kasim Riau, Universitas Muhamadiyah } \\
\text { Riau and Universitas Negeri Padang. Conducted through a formulated survey involving } \\
115 \text { science education students among those universities, the data were collected } \\
\text { through digital literacy questionnaire adapted from "DigComp } 21 \text { the digital competence } \\
\text { framework for citizens". The data analysis used descriptive and inferential statistics } \\
\text { through SPPS } 23 \text { for windows application. Based on results obtained in this line of } \\
\text { research, it showed that the digital literacy of pre-service science teachers was in the } \\
\text { medium category with a score of } 61.8 \% \text {, and therefore, it indicated that there was no } \\
\text { significant effect based on educational institution factors. The majority of students have } \\
\text { low skills to create digital contents. }\end{array}$ \\
\hline
\end{tabular}

To cite this article:

Ilhami, A., Diniya, D., Susilawati, Vebrianto, R. (2021). Digital Literacy of Pre-Service Science Teachers as Reflection of Readiness Toward Online Learning in New Normal Era. Thabiea : Journal of Natural Science Teaching, Vol 4 (2), 207-216.

\section{Introduction}

The COVID-19 pandemic still exists in the world. This outbreak is caused by new variant of coronavirus family that cause symptoms of acute respiratory infection such as fever, cough and shortness of breath. The virus has caused global anxiety hence World Health Organization (WHO) declared a health emergency and then officially declared the corona virus (COVID-19) as a pandemic on March 9, 2020 (WHO, 2020). Most importantly, a number of countries have chosen to carry out regional lockdowns or large-scale social restrictions to reduce the spread of the virus, and give time for the health team to prepare for a surge in patients. Moreover, Indonesian government first established the large-scale social restrictions on April 10, 2020 (BBC, 2020)

The Covid-19 pandemic has certainly not only affected the health aspect but also the education sector (Lazonder et al., 2020). Teachers and students cannot carry out face-to-face learning to protect themselves and others from the virus. The Ministry of Education and Culture of Indonesia (MOEC of Indonesia) has issued 3 forms of learning system policies since the COVID-19 outbreak was declared. Firstly, the learning process has been transformed from offline to online since March 2020. Secondly, the government implemented a second policy regarding the learning guide for the odd semester of the 2020/2021 academic year. MOEC Indonesia permits to expand the implementation of face-to-face learning for the green zone and 
the yellow zone based on the results of the COVID-19 national task force. Thirdly, MOEC Indonesia has issued learning guidelines for implementing the even semester, 2020/2021 academic year. Indonesia government provided full permit to local governments, schools and parents to carry out face-to-face learning but they shall follow the health protocol for preventing the spread of COVID-19 (Kompas, 2020). In early 2021, MOEC Indonesia only implemented large-scale area restrictions specifically for 7 provinces in Indonesia.

Distance learning is a learning activity between teachers and students who are separated by place and time (Moore et al., 2011). Online learning is a type of distance learning that utilizes technological media so that the learning process can also be carried out at the same time even though the teacher and students are in different places (Laelasari, 2021). Teachers and students are in different locations which are only connected by technological devices such as smartphones, tablets or computers. Therefore, digital literacy is one of the skills that students must have (Buchholz et al., 2020). The rapid development of technology requires educators to be literate and able to use technology. Teachers are required to have both skills, namely teaching and using digital media (Tejedor et al., 2020; Tyner, 2011). If teachers have difficulty operating digital communication tools, it will interfere with the smooth running of learning in the digitalization era like today (Akbar \& Anggaraeni, 2017).

Digital literacy is the keyword in an effort to build civilized communication in the digital era (Nash, 2020). The concept of digital literacy can be interpreted in various ways. It can be defined as the abilities needed by each individual to be able to live, learn and work in a digital community environment (Koltay, 2011). Digital literacy is the ability to access, manage, understand, integrate, communicate, evaluate and create information safely and appropriately through digital devices and networked technologies for participation in economic and social life (UNESCO, 2018). One of the efforts to develop a comprehensive digital literacy framework was carried out by the European Union's Joint Research Center which developed the DigComp (Digital Competence Framework for Citizens) concept which contains 5 digital literacy competencies, namely 1) information and data literacy; 2) Communication and collaboration; 3) Digital content creation; 4) Safety; and 5) Problem solving (Carretero et al., 2017a).

Science teacher candidates shall have digital literacy skills to face the new normal era learning. Science learning output expects students to be able to learn about themselves and their surroundings. One of the characteristics of science learning is giving students experience to do experiments or practicum. As online-based learning is massive, the implementation of science practicum certainly cannot be done face to face, but uses digital technology, including Virtual Reality (VR) practicum, using e-learning platforms or social media such as Facebook live streaming \& You Tube live streaming (Rachmawati et al., 2020). This shows that science teacher candidates must have good digital literacy capabilities to face online-based learning. Research to analyze the digital literacy achievements of prospective teachers is very important so that it becomes meaningful input for higher education stakeholders to evaluate the learning process comprehensively (Sadaf \& Gezer, 2020). This study seeks to analyze the digital literacy on science education students at UIN Sultan Syarif Kasim Riau, Universitas Negeri Padang and Universitas Muhammadiyah Riau. 


\section{Method}

The formulated data were collected using a questionnaire measuring digital literacy adapted from DigComp21 The digital competence framework for citizens (Carretero et al., 2017b). The form of the instrument used is a questionnaire with a Likert Scale model. To fill in each statement item in the form of a Likert Scale, 4 alternative answers have been provided and each answer is worth 1 to 4 according to the level of the answer. For further details can be seen in the following Table 1.

Table 1. Digital Literacy Instrumentation Assessment Scale

\begin{tabular}{cc}
\hline Answer Alternative & Scale \\
\hline Almost always & 4 \\
\hline Always & 3 \\
\hline Rarely & 2 \\
\hline Never & 1
\end{tabular}

The first step in making the instrument is creating a grid of questionnaire questions. The digital literacy questionnaire grid is in Table 2.

Table 2. A Grid of Digital Literacy Questionnaire

\begin{tabular}{|c|c|c|}
\hline Domain & Indicator & $\begin{array}{l}\text { Question } \\
\text { Number }\end{array}$ \\
\hline \multirow{3}{*}{$\begin{array}{l}\text { Data and } \\
\text { Information } \\
\text { Literacy }\end{array}$} & Search data, information and digital content & $1,2,3,4,5$ \\
\hline & $\begin{array}{l}\text { Evaluation of data, information and digital } \\
\text { content }\end{array}$ & $6,7,8$ \\
\hline & $\begin{array}{l}\text { Data management, information and digital } \\
\text { content }\end{array}$ & 9,10 \\
\hline \multirow{3}{*}{$\begin{array}{l}\text { Communication } \\
\text { and Collaboration }\end{array}$} & Interaction via digital devices & $11,12,13,14$ \\
\hline & Sharing via digital technology & 15,16 \\
\hline & $\begin{array}{l}\text { Engage in social community through the use } \\
\text { of social media }\end{array}$ & $17,18,19,20,21$ \\
\hline \multirow{3}{*}{$\begin{array}{l}\text { Digital Content } \\
\text { Creation }\end{array}$} & Developing digital content & $22,23,24,25,26,27$ \\
\hline & $\begin{array}{l}\text { Integration and re-elaboration of digital } \\
\text { content }\end{array}$ & 28 \\
\hline & Copyright and license & $29,30,31$ \\
\hline \multirow[t]{2}{*}{ Safety } & Digital device security & $32,33,34,35$ \\
\hline & Health care behaviour & 36,39 \\
\hline Problem Solving & Technical problem solving & $40,41,42,43,44$ \\
\hline
\end{tabular}

Before the instrument is used in the current research, the instrument needs to be validated. There are two types of validity used in this study. First, content validity by asking experts for judgment. The expert judgment process involved 4 expert lecturers whose aim was to provide suggestion on the suitability of the statement items with digital literacy indicators. After going through the content validity process, questionnaires were distributed to 30 students and analyzed by item analysis (empirical validity). Item analysis was carried out by calculating the correlation between the item score instruments and the total score. The instrument is 
declared valid if it has a correlation of more than 0.6 (Arikunto, 2010). The validity test used the Pearson correlation so that 44 statements were declared valid Then the questionnaire reliability test used Cronbach alfa with reliable results (0.7). When interpreted based on predetermined criteria, the digital literacy instrument has high reliability. After the instrument was declared valid and reliable, the instrument was distributed to 115 respondents consisting of students from Science Education Department at UIN Sultan Syarif Kasim, Universitas Muhamadiyah Riau University and Universitas Negeri Padang. The respondents were selected by purposive sampling method. The digital literacy score is obtained by calculating the raw score divided by the maximum score multiplied by the constant $(100 \%)$ then to determine the level of digital literacy using a rubric on Table 3 (Igbokwe, 2016).

Table 3. Digital Literacy Level Category

\begin{tabular}{cc}
\hline Score $(\boldsymbol{\%})$ & Scale \\
\hline$<60$ & Low \\
\hline $60-79$ & Average \\
$\geq 80$ & High \\
\hline
\end{tabular}

Data analysis uses descriptive and inferential statistics, namely the Kruskal Wallis test using the SPSS 23 program for windows.

\section{Results and Discussion}

Digital literacy is one of the abilities that prospective teachers must have to access, manage, understand, integrate, communicate, evaluate and create information securely through digital devices. In this study, a digital literacy questionnaire used the DigComp21 framework to determine science education students' digital literacy of UIN Sultan Syarif Kasim Riau (UIN SUSKA), Universitas Negeri Padang (UNP) and Universitas Negeri Muhammadiyah Riau (UMRI). The components of digital literacy are data and information literacy (DIL), communication \& collaboration (CC), Digital content creation (DCC), safety (SF) and problem solving (PS). Judging from each digital literacy domain, the student have scores ranging from $49 \%-73 \%$, which means they are in the low to medium category range. Student digital literacy score data for each domain is presented in Figure 1.

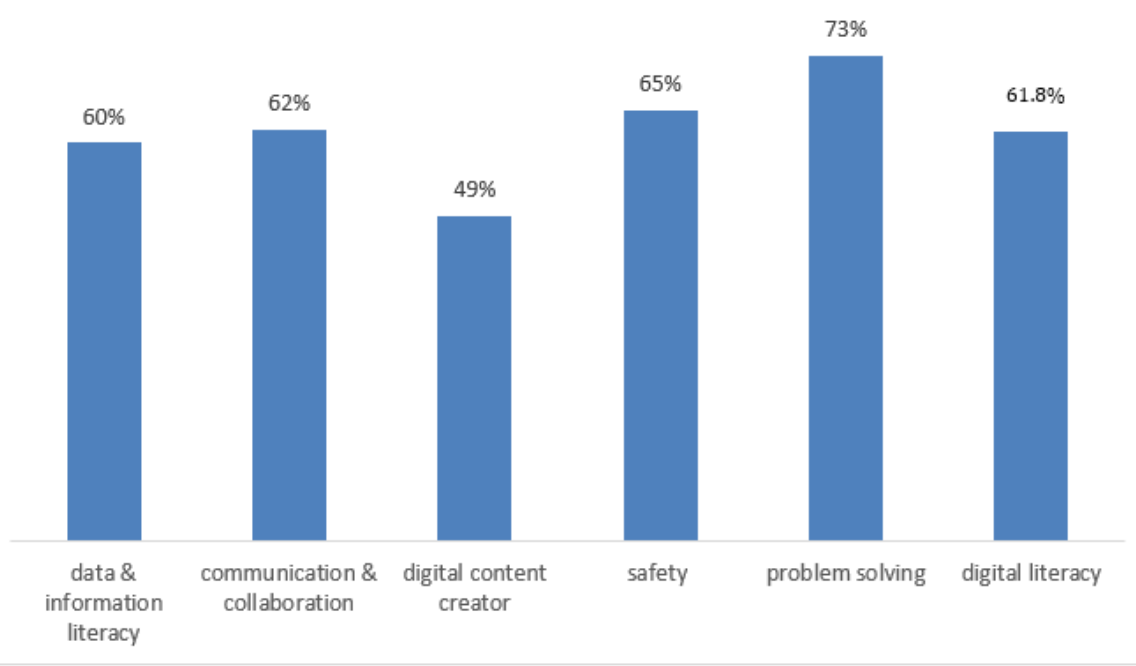

Figure 1. Science Education Students’ Digital Literacy 
In the DIL domain, the average score of students was $60 \%$ (medium category). This shows that science education students understand enough about how to browse, evaluate and manage data and information using digital devices. It is due to habits during learning; lecturers require students to look for relevant assignment references. Reference sources must also be valid. For example, students are required to use journal articles as assignment references. Then the student must be able to find reputable journals and relevant topics. That is, it requires students to be able to search and filter data correctly. According to Sung's research, the interaction between users and users can make students make discoveries independently on the internet ernet (Sung et al., 2016). The results of other studies also show that digital literacy has a direct positive relationship with students' online information searching strategies. Further, digital literacy was found to be a mediating factor to university students' information searching strategies (Atoy et al., 2020). Digital literacy is a primary skill for students. The learning process requires digital literacy skills like the use of technology. The need for digital literacy is motivated by the many lecture activities that involve digital technology devices. Students will use laptops and other technological devices to complete their projects. The development of technological flows must be balanced with adequate knowledge and abilities to meet these needs. With digital literacy skills, students can easily access, search and evaluate additional material in digital media. Digital literacy contributes to the effectiveness of student lectures. In this pandemic era, virtual interactions are more frequent than before in the world. Smartphones as a means of communication and the main information for online activities. Smartphone is often considered negatively influenced but in this pandemic era, it plays an importance roles. Smartphone have become a major necessity in distance learning, among other information and communication technology tools. According to a DigiTimes report, overall smartphone shipments in 2021 will be up 6.4 percent over the previous year. Then Kominfo mentioned that smartphones have started since the age of six (Adeni \& Harahap, 2021)

In the $\mathrm{CC}$ domain, the average student score was $62 \%$ in the medium category. This shows that science students already have the ability to use digital devices, share digital content and participate in cyberspace using digital devices. there is a qualitative study involving ten teachers who interviewed about the teaching strategies of millennial generation students Using focus group interviews, the data revealed that six strategies were employed by the teachers in teaching and engaging with the students which include promoting collaboration, promoting students' engagement inside and outside the classroom, encouraging knowledge creation, developing critical thinking, applying research-based teaching and incorporating technology. These findings have brought significant changes to the teachers in adjusting their teaching paradigm and engaging students to learning i.e. from teacher-centred to student-centred learning. Therefore, teachers at higher education particularly, should consider appropriate teaching strategies that are compatible with the Millennial generation's characteristics in engaging them into learning (Hatmanto \& Eko Purwanti, 2020). Generation $\mathrm{Z}$ is known as the literate generation and connected through digital social media networks, connected via the internet. As a generation that is accustomed to utilizing technological advances, it certainly impacts daily life. Moreover, the ease of accessing the internet creates the internet as the main reference source in finding information (Cohen, 2020) 
For the DCC domain, science education students have an average score of $49 \%$ in the low category. This shows that science education students do not yet have sufficient abilities in developing digital content through application programs, integrating various digital content and the ethics of using copyrighted digital content. Video editing skills are one of the important skills. The video editor is responsible for collecting and processing several available video materials into one video ready to be distributed. This material can be in the form of footage, dialogue, interviews, graphics, and sound effects. In producing video works, editors have an important role in the post-production process, determining the quality of the products made. In this era, prospective teachers must-have skills for video editing as a learning medium. Multimedia learning is one of the important roles in online learning. The use of multimedia can create a pleasant classroom atmosphere. Therefore, educators in the digital era must have the skills to produce creative videos that attract students' attention. Multimedia can develop sensory abilities and attract attention and interest. Computer technology Research (CTR) states that people can only remember $20 \%$ of what is seen and $30 \%$ of what is heard. Then people can remember $50 \%$ what is seen and heard and $80 \%$ of what is seen, heard and done all at once. Multimedia can present information that can be seen, heard, and done, so multimedia is very effective as a complete tool in teaching and learning (Munir, 2015).

In the SF domain, the average score of science education students was $65 \%$ in the moderate category. This shows that students have understood and applied the behaviour of safeguarding data privacy and health care behaviour to protect the effects caused by the use of digital devices. In the PS aspect, the average score of science education students is $73 \%$ in the moderate category. This shows that science education students already understand actions to solve problems in the use of digital devices.

Science education students who were used as research samples were from UIN SUSKA, UNP and UMRI. UIN SUSKA is a state university under the auspices of the Ministry of Religion Affairs, located in Riau province. This campus has a department of science education which was established in 2017. Then, UNP is a public university under the auspices of the ministry of education and culture located in the province of West Sumatra. This campus has a department of science Education which was established same with UIN SUSKA. UMRI is a private university under the auspices of the ministry of education and culture which is located in Riau province. This campus has department of science education study program which was also established in 2017. All universities have same age which established 4 years ago.

The digital literacy level of science education students of UIN SUSKA, UMRI and UNP is in the medium category with an average digital literacy score of $62.2 \%, 61.5 \%$ and $6.8 \%$. In DIL domain, UIN SUSKA and UNP students have the same score, namely $61 \%$ in the moderate category. UMRI students have a score of $59 \%$ with a low category. In CC domain, the digital literacy level of UIN SUSKA, UMRI and UNP students is in the medium category. The digital literacy score of UIN SUSKA and UNP students is 63\%, while UMRI has a score of $60 \%$. In DCC domain, all students from the UIN SUSKA, UMRI and UNP campuses are in the low category with an average score of 50\%, 47\% and 49\% respectively. In PS domain, all students from the UIN SUSKA, UMRI and UNP campuses are in the medium category. The highest score, $74 \%$, was obtained by UMRI students, while UIN SUSKA and UNP students got a score of $72 \%$. Then on the safety aspect, all students from the UIN SUSKA, UMRI and UNP 
campuses were in the medium category with an average score of $65 \%, 67 \%$ and $64 \%$ respectively. Digital literacy data for each domain is presented in Figure 2.

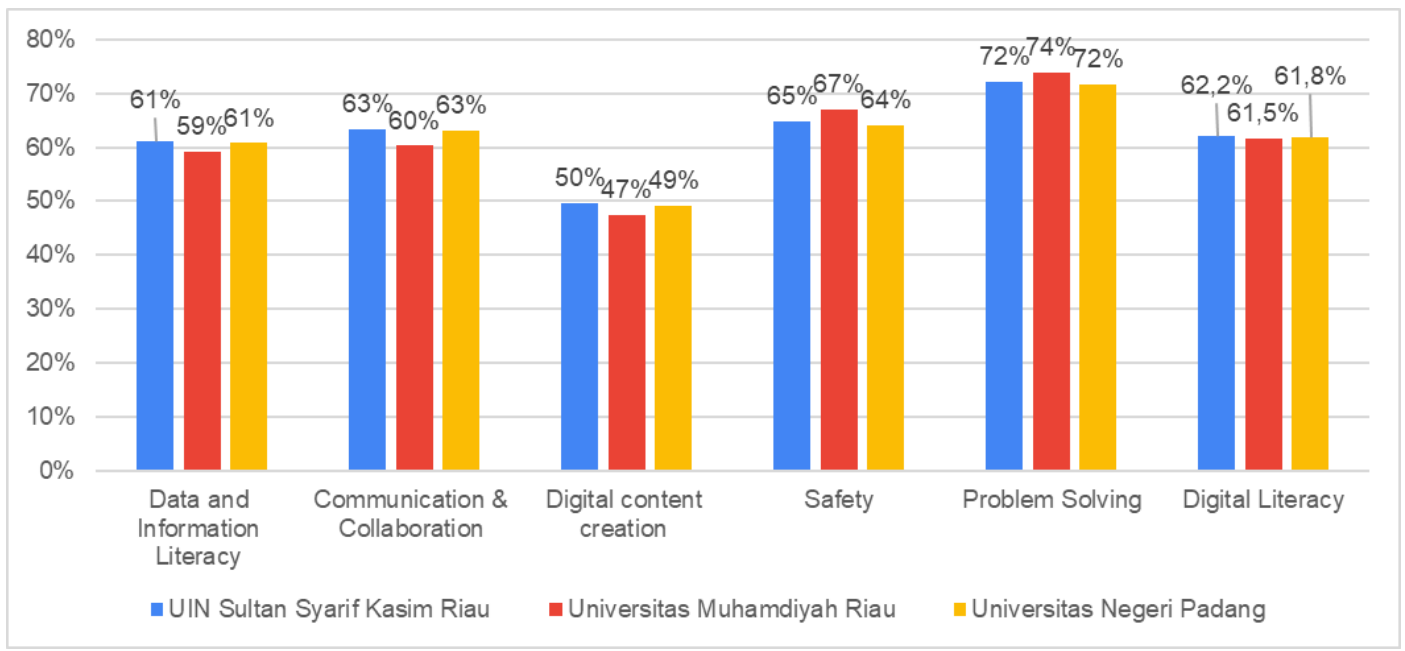

Figure 2. Level of students' digital Literacy based on universities

The universities used in this research basically represent institutions under the auspices of the Ministry of Education and Culture (Kemendikbud) and universities under the auspices of the Ministry of Religion Affairs (Kemenag). Overall, the average percentage score of students' digital literacy is in the medium category $(61.8 \%)$. UIN SUSKA students' digital literacy was $62.2 \%$, UNP was $61.8 \%$ and UMRI was 61.5 . The category for the digital level of science education students in each university is in the medium category. This shows that students have sufficient abilities to access, manage, understand, integrate, communicate, evaluate and create information securely through digital devices. Data on student digital literacy levels can be seen in the table. 4

Table 4. Level of Students' digital literacy of UIN SUSKA, UMRI dan UNP

\begin{tabular}{lcl}
\hline \multicolumn{1}{c}{ University } & Digital Literacy & Category \\
\hline UIN Sultan Syarif Kasim Riau $(\mathrm{n}=67)$ & $62,2 \%$ & Medium \\
Universitas Muhamdiyah Riau $(\mathrm{n}=12)$ & $61,5 \%$ & Medium \\
Universitas Negeri Padang $(\mathrm{n}=36)$ & $61,8 \%$ & Medium \\
Average & $61,8 \%$ & Medium \\
\hline
\end{tabular}

To find out whether there is a significant difference in the level of digital literacy of students based on differences in institutions, researchers used hypothesis testing using inferential statistics. The initial stage is the normality test using the Kolmogorov-Smirnov test. The results of the normality test showed that UIN SUSKA students' digital literacy data were not normally distributed (sign $<0.05$ ), UMRI students' digital literacy data were normally distributed (sign.> 0.05) and UNP students' digital literacy data were normally distributed (sign $>0.05$ ). Because one of the data was not normally distributed, the statistical test used was a non-parametric statistical test, namely the Kruskal Wallis test. 
Tabel. 5 Normality Test Result

\begin{tabular}{llccc}
\multirow{2}{*}{ Data } & \multicolumn{1}{c}{ University } & \multicolumn{3}{c}{ Kolmogorov-Smirnov } \\
\cline { 2 - 5 } Digital Literacy & Statistic & Df & Sig. \\
\hline & $\begin{array}{l}\text { UIN Sultan Syarif Kasim } \\
\text { Riau }\end{array}$ & .133 & 52 & .023 \\
\cline { 2 - 5 } & $\begin{array}{l}\text { Universitas Muhamadiyah } \\
\text { Riau }\end{array}$ & .177 & 12 & $.200^{*}$ \\
\cline { 2 - 5 } & Universitas Negeri Padang & .125 & 36 & .173
\end{tabular}

Based on the hypothesis test using the Kruskal Wallis test, it shows a sign value $>0.05$, which means that $\mathrm{H}_{0}$ is accepted. This means that there is no significant difference in the digital literacy of science education students at UIN SUSKA, UNP and UMRI. Kruskal Wallis test results data are presented in Table 6.

Tabel 6. Result of Kruskal Wallis Test

\begin{tabular}{lr} 
& \multicolumn{2}{c}{$\begin{array}{c}\text { Digital } \\
\text { Literacy }\end{array}$} \\
\hline Chi-Square & .315 \\
\hline df & 2 \\
\hline Asymp. Sig. & .854
\end{tabular}

Students from all three universities belong to Generation Z. Students have an age range of 18-24 years. According to Shatto \& Erwin (2017) Generation Z have grown up in a post$9 / 11$ world characterized by global terrorism and economic distress. Information is shared and streamed in real time, and civil uprisings are organized via social media. These generations possess characteristics that are unique to growing up in the digital age.

\section{Conclusion}

The digital literacy level of science education students at UIN Sultan Syarif Kasim Riau, Universitas Negeri Padang and Universitas Muhammadiyah Riau are in the medium category with their respective scores of $62.2 \%, 61.5 \%$ and $61.8 \%$. There was no significant difference in the digital literacy scores of science education students at UIN Sultan Syarif Kasim Riau, Riau Muhamadiyah University and Padang State University (sign. 0.854>0.05)

\section{Acknowledgment}

Thank you to LPPM UIN Sultan Syarif Kasim Riau for giving research permission. Then the authors would like to thank to Head of Science Education Program at UIN Sultan Syarif Kasim Riau, Universitas Negeri Padang and Universitas Muhammadiyah Riau who have permitted to collect this research data.

\section{References}

Adeni, S., \& Harahap, M. A. (2021). Aksesibilitas Anak Terhadap Media : Internet Sehat Bagi Anak. Jurnal Profesional FIS UNIVED, 8(1).

Akbar, M. F., \& Anggaraeni, F. D. (2017). Teknologi Dalam Pendidikan : Literasi Digital Dan 
Self-Directed Learning Pada Mahasiswa Skripsi. Jurnal Indigenous, 2(1), 28-38. Arikunto, S. (2010). Prosedur Penelitian: Suatu Pendekatan Praktek. Rineka Cipta.

Atoy, M. B., Garcia, F. R. O., Cadungog, R. R., Cua, J. D. O., Mangunay, S. C., \& de Guzman, A. B. (2020). Linking digital literacy and online information searching strategies of Philippine university students: The moderating role of mindfulness. Journal of Librarianship and Information Science, 52(4), 1015-1027. https://doi.org/10.1177/0961000619898213

BBC. (2020). PSBB Jakarta mulai 10 April selama dua minggu, namun pakar menyebut hasil efektif satu bulan untuk tekan Covid-19 - BBC News Indonesia. https://www.bbc.com/indonesia/indonesia-52194441

Buchholz, B. A., DeHart, J., \& Moorman, G. (2020). Digital Citizenship During a Global Pandemic: Moving Beyond Digital Literacy. Journal of Adolescent \& Adult Literacy, 64(1), 11-17. https://doi.org/https://doi.org/10.1002/jaal.1076

Carretero, S., Vuorikari, R., \& Punie, Y. (2017a). DigComp 2.1: The Digital Competence Framework for Citizens. With eight proficiency levels and examples of use. In Publications Office the European Union. http://publications.jrc.ec.europa.eu/repository/bitstream/JRC106281/webdigcomp2.1pdf_(online).pdf

Carretero, S., Vuorikari, R., \& Punie, Y. (2017b). The Digital Competence Framework for Citizens With eight proficiency levels and examples of use.

Cohen, S. (2020). How Teachers conceive their Role when Working with Generation Z Pupils in a Technological Learning Environment - ProQuest. Proquest Dissertation Publishing. https://www.proquest.com/openview/4dab4f6dcf091a213b077ccdcf4212c8/1?pqorigsite $=$ gscholar $\& \mathrm{cbl}=2026366 \&$ diss $=\mathrm{y}$

Hatmanto, E. D., \& Eko Purwanti. (2020). Strategies in Teaching and Engaging the Millennial Generation. IJLEAL, 10(1).

Igbokwe, B. A. (2016). Environmental Literacy Assessment: Assessing the Strength of an Environmental Education Program (EcoSchools ) in Ontario Secondary Schools for Environmental Literacy Acquisition. University of Windsor.

Koltay, T. (2011). The media and the literacies: media literacy, information literacy, digital literacy. Media, Culture \& Society, 33(2), 211-221. https://doi.org/10.1177/0163443710393382

Kompas. (2020). Mendikbud: Januari 2021 Sekolah Boleh Tatap Muka. https://edukasi.kompas.com/read/2020/11/20/161556771/mendikbud-januari-2021sekolah-boleh-tatap-muka-ini-syaratnya?page=all

Laelasari, I. (2021). Analysis of the Implementation of Technology-based Outdoor Learning Model in Science Subject ( Plant Diversity) Analisis Penerapan Strategi Pembelajaran Daring Dengan Model Outdoor Learning Berbasis Teknologi Pada Pembelajaran IPA ( Keragaman Tumbuhan ). 7(1), 14-25. https://doi.org/10.32332/ejipd.v7i1.2308

Lazonder, A. W., Walraven, A., Gijlers, H., \& Janssen, N. (2020). Longitudinal assessment of digital literacy in children: Findings from a large Dutch single-school study. Computers \& Education, 143, 103681. https://doi.org/https://doi.org/10.1016/j.compedu.2019.103681

Moore, J. L., Dickson-Deane, C., \& Galyen, K. (2011). E-Learning, online learning, and distance learning environments: Are they the same? Internet and Higher Education, 14(2), 129-135. https://doi.org/10.1016/j.iheduc.2010.10.001

Munir. (2015). Multimedia (Konsep \& Aplikasi dalam pendidikan) (Ruswandi \& Nurfitriansyah (eds.)). Alfabeta.

Nash, C. (2020). Report on Digital Literacy in Academic Meetings during the 2020 COVID-19

Lockdown. In Challenges (Vol. 11, Issue 2). https://doi.org/10.3390/challe11020020

Rachmawati, Y., Ma'arif, M., Fadhillah, N., Inayah, N., Ummah, K., Siregar, M. N. F., 
Amalyaningsih, R., C., F. A. A., \& F., A. A. (2020). Studi Eksplorasi Pembelajaran Pendidikan IPA Saat Masa Pandemi COVID-19 di UIN Sunan Ampel Surabaya. Indonesian Journal of Science Learning, Volume 1,(1), 32-36. http://jurnalftk.uinsby.ac.id/index.php/IJSL/article/view/633

Sadaf, A., \& Gezer, T. (2020). Exploring factors that influence teachers' intentions to integrate digital literacy using the decomposed theory of planned behavior. Journal of Digital Learning in Teacher Education, 36(2), 124-145. https://doi.org/10.1080/21532974.2020.1719244

Shatto, B., \& Erwin, K. (2017). Creative nursing. Creative Nursing, 23(1), 24-28. https://doi.org/10.1097/00000446-193601000-00022

Sung, Y.-T., Chang, K.-E., \& Liu, T.-C. (2016). The effects of integrating mobile devices with teaching and learning on students' learning performance: A meta-analysis and research $\begin{array}{llll}\text { synthesis. Computers \& } \quad \text { Education, } & \text { 252-275. }\end{array}$ https://doi.org/https://doi.org/10.1016/j.compedu.2015.11.008

Tejedor, S., Cervi, L., Pérez-Escoda, A., \& Jumbo, F. T. (2020). Digital Literacy and Higher Education during COVID-19 Lockdown: Spain, Italy, and Ecuador. In Publications (Vol. 8, Issue 4). https://doi.org/10.3390/publications8040048

Tyner, K. (2011). Media Literacy and The Promise of School Change. Journal of Media Literacy, May.

UNESCO. (2018). A Global Framework of Reference on Digital Literacy for Indicator 4.4.2. Information Paper, 51(51), 1-146.

WHO. (2020). In WHO global pulse survey, 90\% of countries report disruptions to essential health services since COVID-19 pandemic. https://www.who.int/news-room/detail/31-082020-in-who-global-pulse-survey-90-of-countries-report-disruptions-to-essential-healthservices-since-covid-19-pandemic 